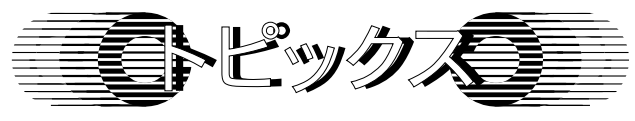

\section{ジベレリンによる 転写調節因子の機能制御}

東京大学大学院理学系研究科生物科学専攻 石田さらみ 広島大学大学院理学研究科生物科学専攻高橋陽介

\section{1. はじめに}

光エネルギーを化合物に転換することで，地球上に おける他のすべての生命を支える植物は, 自らは移動 せず，大地に根を張り，その生存の領域を広げ，外部 環境の激しい変化を克服して生育する。そのために植 物は柔軟な形態形成のメカニズムを発達させてきた. 細 胞の形を自在に変化させ，その細胞を積み上げて個体 を形成するシステムは，植物が 4 億年前に陸上に進出 する際に獲得したものである. 周囲の環境変化に適応 し太陽光の捕捉効率を最適化するために, 自在に背丈 を変化させる機構は陸上植物の繁栄に必須であった. ゲ ノムに刻まれた発生のプログラムから形態形成制御に 至る経路と環境情報から形態形成制御への経路はとも に植物ホルモンを介している. 植物の柔軟な形態形成 を理解するためには植物ホルモンの作用機構を解明し なければならない，

ジベレリン $(\mathrm{GA})$ は植物の発芽, 節間の成長などに 顕著な促進作用を示す植物ホルモンである. GA は生物 学上の, あるいは農業上の歴史的偉業に深くかかわっ てきた。メンデルが遺伝学の基本法則を見いだす際に 用いた背丈の低い形質のエンドウは，実は $\mathrm{GA}$ 生合成 酵素遺伝子の変異体であった. 世界の人口はこの 100 年 間で約 40 億増加したが, 1960 年代に目覚ましい収穫率 の向上をもたらし，現在の人類の食を支えている「緑 の革命」のコムギ，イネの新品種はいずれも GA 関連 の突然変異体である. GAが植物の形や生活環にいかに 大きな影響を与えているかがわかる.

動物と植物の間のゲノムや信号伝達の比較から受け
る印象は, 形態や生存戦略の差違を反映した両者の違 いよりはむしろ類似性であった，例えば，GA応答は， RGA（repressor of gal-3）など信号伝達の負の制御因子 が $\mathrm{GA}$ 刺激によりユビキチン-プロテアソームの系で分 解されることにより引き起こされる1).この経路の基本 構造は, 個々のタンパク質のモチーフの違いはあるも のの, 免疫系の転写因子 NF-kB の活性化の経路に同じ といってよい. 植物ゲノムの特徵の 1 つは遺伝子機能 の重複性である. シロイヌナズナの遺伝子は約 26000 程 度と推定されているが，そのうち6 割の遺伝子には相 同性の高い関連遺伝子 (パラログ) が存在する. シロ イヌナズナでは現在, ほとんどの遺伝子の挿入変異体 が入手可能になっているが, 遺伝子の機能重複のため 重要な遺伝子の機能喪失変異体であっても明確な表現 型を示さないものがある.

転写因子に関しても, シロイヌナズナでは約 2000 個 の存在が予想されているが, 機能重複のため従来の遺 伝学的手法だけでは機能解析に限界がある. 最近, 高 木らのグループはエチレン応答に関する転写抑制因子 ERF3 内の 12 アミノ酸からなるEARモチーフを他の転 写活性化因子に接続すると, これをリプレッサーに変 換できることを見いだした，機能重複のみられる転写 活性化因子（CUCやAtMYB23）にEAR モチーフを接 続して植物体に導入すると, 関連遺伝子の機能がすべ て抑制されたと考えられる表現型を示した 2). この抑制 システムは転写因子の機能解析系として有望と思われ る.

活性型 GA はプラスチド，小胞体，細胞質での多段 階の反応により合成される.GAの主要な生合成反応は 6 種類の酵素により触媒される. 矮性変異体のうち GA の投与により成長の回復するものは, GA生合成酵素遺 伝子のいずれかに欠損のあるものが多い.メンデルの エンドウは, GA 生合成の最終段階を触媒する GA 3-酸 化酵素をコードする遺伝子の変異体である.

植物の安定した成長のためには植物体の GA 量が一 定に維持されることが望ましい，植物体の $\mathrm{GA}$ 量が変 化すると, 植物はフィードバック制御を発動させ $\mathrm{GA}$ 量 を調整する。例えば, GA 生合成阻害剂を用いて植物体 の $\mathrm{GA}$ 量を人為的に低下させると, GA 生合成反応の終

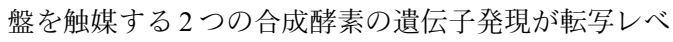
ルで上昇し, GA 分解酵素の遺伝子発現が減少する. 逆

\title{
Functional Regulation of a Plant Transcription Factor by Gibberellin Levels
}

Sarahmi ISHIDA ${ }^{1}$ and Yohsuke TAKAHASHI ${ }^{2}$

${ }^{1}$ Department of Biological Sciences, Graduate School of Science, The University of Tokyo

${ }^{2}$ Department of Biological Science, Graduate School of Science, Hiroshima University 


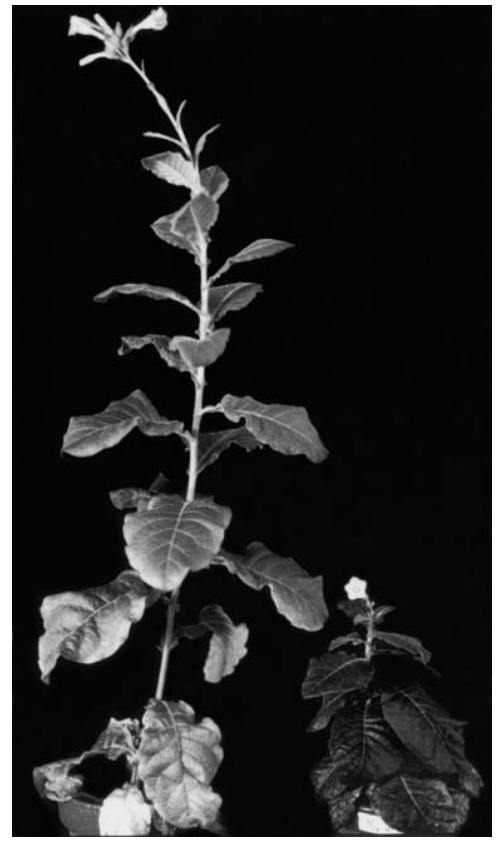

Fig. 1 Phenotypes of transgenic tobacco plants expressing the dominant negative form of RSG. Comparison of SR1 (Nicotiana tabacum cv Petit Havana SR1) tobacco (left) and the transgenic tobacco harboring the dominant negative form of RSG (right).

に, 植物体に過剩の GA を投与すると, GA 合成酵素遺 伝子の発現は抑制され, GA 分解酵素の遺伝子発現が上 昇する. この正負の協調したフィードバック制御によ り GAの恒常性は維持されると考えられる ${ }^{1)}$. GAフィー ドバック制御機構の解明では，植物体の GA 量変化を 感知して機能を変化させるタンパク質を同定すること が重要になる.

\section{2. bZIP型転写因子RSG}

RSG (repression of shoot growth) は, 塩基性領域ロイ シンジッパー（bZIP）構造をもつタバコの転写活性化 因子である. RSG 350 アミノ酸残基からなり，bZIP 構造の他に, 転写の活性化に関与すると考えられる酸 性アミノ酸に富む領域, セリンに富む領域およびグル タミンのクラスターをもつ. 直接の標的遺伝子の 1 つ はGA合成系のent-カウレン酸化酵素遺伝子である. シ ロイヌナズナではRSG と顕著な相同性を示す遺伝子が 13 存在していて, 機能的な重複が予想された. 実際, 1 つの遺伝子へのT-DNA（transferred DNA）扱入変異で は際だった形態の変化は認められなかった，そこでド ミナントネガティブ型 RSG による植物体の RSG の機 能抑制を試みた. すると, GA 合成系の ent-カウレン酸
化酵素遺伝子の発現低下により活性型 GA 量が約 $1 / 10$ に減少し, 植物の成長が著しく阻害され矮性を示した (Fig. 1). この矮化した形質転換植物に GA を投与する と成長が回復した. RSGは植物体の GA 量調節を介し て植物の成長を制御しているのである ${ }^{3)}$.

\section{RSGと相互作用する14-3-3タンパク質}

RSGの機能制御機構を調べるためにRSG と特異的に 相互作用するタンパク質を酵母 two-hybrid 法により探 索した. 同定されたタンパク質の1つのグループは143-3とよばれるもので, 動物, 植物, 菌類など真核生物 に広く存在する制御因子であった ${ }^{4)}$. 免疫沈降法による 解析から RSG と 14-3-3 は植物細胞内で実際に複合体を 形成していることが示された. 14-3-3 タンパク質その ものには, 特定の機能や酵素活性は認められていない. 14-3-3 タンパク質は多くの場合二量体を形成し, 他の さまざまなタンパク質と結合して，その活性や細胞内 局在を調節している. 細胞周期を制御する CDC 25 , 細 胞死を促進する BAD, 孔辺細胞の $\mathrm{H}^{+}$-ATPase などが 143-3の標的タンパク質として有名である5).

14-3-3の結合配列のうち, さまざまな生物種で保存 されているのはリン酸化セリンを中心とするモチーフ (RSXpSXP) である. RSG と 14-3-3 との結合にはRSG の 114 番目のセリン残基が必須であった。合成リン酸 化ペプチドを用いたプルダウンアッセイ※などから, こ のセリン残基のリン酸化によりRSGと14-3-3 との結合 が制御されていることが明らかになった ${ }^{6}$. RSGの 114 番目のセリン残基をアラニンに置換した変異型 RSG （S114A）は, 植物細胞内で野生型 RSGよりも強い転写 活性化能をもつので, 14-3-3 は転写活性化因子RSGの 機能を負に制御していると考えられた。

GFP（green fluorescent protein）との融合タンパク質 を用いてRSGの細胞内分布と14-3-3との結合の関連を 調べてみると, RSG-GFPは細胞全体に散在するのに対 し14-3-3 と結合できないRSG(S114A)-GFPは核に局在 していた ${ }^{4)}$. したがって, 14-3-3によるRSGの負の機 能制御の実体は細胞内局在制御である. すなわち, 143-3 は RSGに結合し細胞質に拘束することで核内の標 的遺伝子から空間的に隔離しているのである. 核外輸 送担体 exportin 1/CRM1の阻害剂レプトマイシンBを用 いた実験から, RSGは核と細胞質をシャトルしている 転写因子であることが示された. 14-3-3はRSG と結合 するとRSGの核内輸送を抑制するか核外輸送を促進す ると考えられた. 14-3-3による核-細胞質シャトルタン パク質の制御の例としてはアフリカツメガエルの CDC25, 哺乳類のFKHRL1, ヒストン脱アセチル化酵 素, TAZなどがある. 

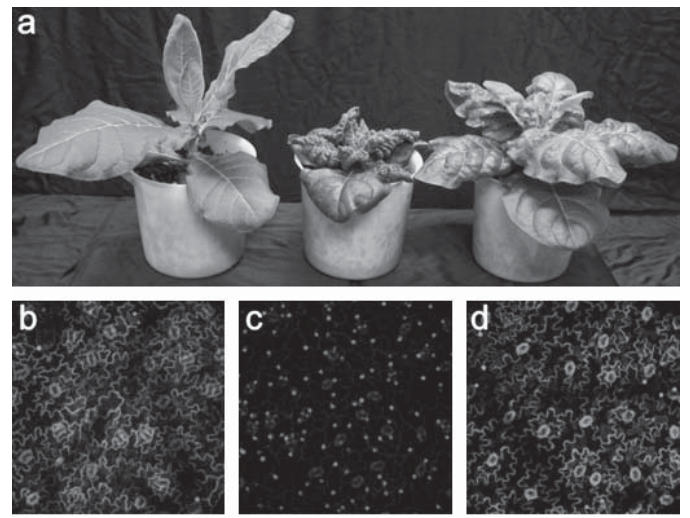

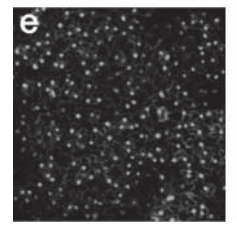

Control

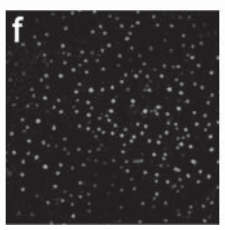

Uni

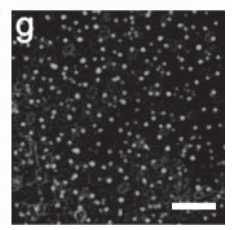

Uni $\rightarrow$ GA
Fig. 2 GAs regulate the intracellular localization of RSG. (a) The effect of uniconazole $P$ on the growth of tobacco. The control untreated tobacco plant is at left, the uniconazole P-treated tobacco plant is in the center, and the GA-treated tobacco plant after treatment with uniconazole $P$ is at right. (b) to (d) Confocal microscopic images of GFP fluorescence in leaves of transgenic tobacco plants expressing RSG-GFP. To inhibit GA biosynthesis, the transgenic plants were treated with uniconazol $\mathrm{P}(\mathrm{c})$ and then with $\mathrm{GA}_{3}{ }^{*}(\mathrm{~d})$. The control indicates normal growth conditions without any treatment (b). (e) to (g) Confocal microscopic images of GFP fluorescence in leaves of transgenic tobacco plants expressing S114A-GFP. The transgenic plants were treated with uniconazol $P$ (f) and then treated with $\mathrm{GA}_{3}(\mathrm{~g})$. The control indicates normal growth conditions without any treatment (e). Uni, plants treated with uniconazole $P$ for 7 days; Uni $\rightarrow G A$, plants treated with uniconazole $P$ for 7 days and then with $\mathrm{GA}_{3}$. Bar $=100 \mu \mathrm{m}$.

\section{GAによるRSGの機能制御}

それではRSGの細胞内局在を制御する刺激とは何だ ろうか? それを調べるためにRSG-GFPを発現する形 質転換植物にさまざまな植物ホルモンなどを与えて, 影 響を調べた，その結果，GAの合成阻害剤ウニコナゾー ルを投与して植物体の GA 量を低下させるとRSG は核 に蓄積し (Fig. 2 の (c) ではドット状の GFP 蛍光が RSG の核局在を示している)，逆に GA を投与すると RSG は核から消失する事を見いだした（Fig. 2)。この結果 は, GA生合成酵素遺伝子の転写調節に関与するRSGの 細胞内局在が, GAによって制御されていることを示し

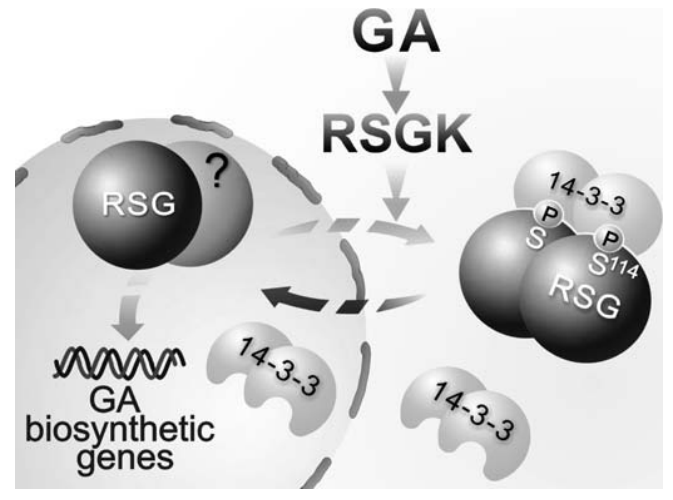

Fig. 3 A model for the functional regulation of RSG by GAs. We propose that GA levels regulate the intracellular localization of RSG by 14-3-3 binding. Dissociation of RSG from 14-3-3 in response to a decrease in GA levels promotes nuclear accumulation of RSG. Active GAs cause cytoplasmic migration of RSG through phosphorylation of Ser-114 of RSG and 14-3-3-binding. RSGK, RSG kinase.

\section{ている6).}

次に GA 量による RSGの細胞内局在制御が 14-3-3 と の結合を介しているのかどうかを調べた，先に述べた ように変異型 RSG（S114A）は14-3-3 との結合能力を 失い, 核に局在する. RSG（S114A）は野生型RSG と 異なり GA の刺激を受けても核から消失せず，核に局 在したままであった。すなわち，GAによるRSGの細 胞内局在制御には14-3-3 との結合が必要であることが 明らかになった. GA 信号伝達系の負の調節因子 RGA, GAIなどは, GA信号を受容するとユビキチン修飾を受 け $26 \mathrm{~S}$ プロテアソーム系により分解され, 核から消失 する。 そこでGAによるRSGの核からの消失にもタン パク質分解が関与しているのかどうかを調べるため, GA 投与後の RSG-GFP融合タンパク質および内在性RSGの 量的変動をウエスタン法により調べた。その結果, GA 量を低下させても，GA を投与しても， RSG タンパク 質の顕著な量的変動は認められないことが判明した6). したがって，GAによるRSGの核からの消失において 主要な役割を果たしているのはタンパク質分解ではな く, 14-3-3 との結合を介した細胞内局在調節と考えら れる (Fig. 3).

植物体の GA 量は, 生合成酵素と分解酵素の協調的 な転写調節によるフィードバック制御により一定範囲 内に維持されると考えられている. 植物体の GA 量低 下時に核に蓄積し, GAを投与すると細胞質へ移動する という RSGの挙動は, この転写因子が GAのフィード バック制御に関与することを示唆する。 これまでの解 析で, RSGの直接の標的遺伝子の 1 つは GA 合成系の 
ent-カウレン酸化酵素遺伝子であることが明らかにされ ている. ところが, この遺伝子は GA フィードバック 制御を受けていない.

それでは, 植物体の GA 量低下時に RSG は核に局在 してどのような遺伝子を制御しているのだろう か? GA フィードバック制御を受けるのは 2 つの GA 生合成酵素（GA 20-酸化酵素, GA 3-酸化酵素）遺伝 子である，そこで，RSGの機能を抑制した形質転換植 物に打けるGA 20-酸化酵素とGA 3-酸化酵素のフィー ドバック制御に変化がないか調べた. その結果, GA 3酸化酵素遺伝子のフィードバック制御はRSGの機能を 抑制した形質転換植物においても正常であったが, GA 20-酸化酵素遺伝子のフィードバック制御は顕著に抑制 されていた6). すなわちRSGの機能抑制により GA 20酸化酵素遺伝子のフィードバック制御が失われたので ある. RSG は植物体の GA 量が低下したときは，核内 で新たな複合体を形成して直接あるいは間接的に GA 20-酸化酵素遺伝子の転写を促進しているのではないだ
ろうか. また RSGの 114 番目のセリン残基をリン酸化 するキナーゼは GA 信号伝達の下流に位置し, RSG と 14-3-3の結合, RSGの細胞内局在, ひいては標的遺伝 子の転写を制御すると予測される. この RSG キナーゼ がGAによるRSGの機能制御の要と考えられ，その実 体の解明が待たれる.

\section{文 献}

1) Fleet C. M. and Sun, T.-P. (2005) Curr. Opin. Plant Biol. 8, 77-85.

2) Hiratsu, K., Matsui, K., Koyama, T. and Ohme-Takagi, M. (2003) Plant J. 34, 733-739.

3) Fukazawa, J., Sakai, T., Ishida, S., Yamaguchi, I., Kamiya, Y. and Takahashi, Y. (2000) Plant Cell 12, 901-915.

4) Igarashi, D., Ishida, S., Fukazawa, J. and Takahashi, Y. (2001) Plant Cell 13, 2483-2497.

5) Roberts, M. R. (2003) Trends Plant Sci. 8, 218-223.

6) Ishida, S., Fukazawa, J., Yuasa, T. and Takahashi, Y. (2004) Plant Cell 16, 2641-2651. 
石田さらみ（いしだ さらみ）

東京大学大学院理学系研究科生物科学専攻助手 連絡先：干113-0033 東京都文京区本郷 7-3-1

E-mail: ishida@biol.s.u-tokyo.ac.jp

高橋陽介（たかはし ようすけ）

広島大学大学院理学研究科生物科学専攻教授

連絡先：干739-8526 東広島市鏡山 1-3-1

E-mail: ytakahas@hiroshima-u.ac.jp 